\title{
ALTERNATIVE LEARNING DURING A PANDEMIC: USE OF THE WEBSITE AS A MATHEMATICS LEARNING MEDIA FOR STUDENT MOTIVATION
}

\author{
Suripah, Weni Dwi Susanti*
}

Universitas Islam Riau, Indonesia

\begin{tabular}{l} 
Article Info \\
\hline Article history: \\
Received Feb 15, 2021 \\
Revised July 24, 2021 \\
Accepted July 26, 2021 \\
\hline
\end{tabular}

Keywords:

Alternative Learning,

Mathematics,

Motivation,

Pandemic,

Website

\begin{abstract}
In March 2020, direct learning activities were transferred online due to the Covid-19 pandemic. There are many alternative technology-based learning media used for online learning systems. However, the use of this media has not been able to increase students' motivation to learn mathematics. One of the media that can be used as an alternative learning media during this pandemic is a website. The purpose of this study was to find out how to use the website as a learning media in the midst of this pandemic, and to determine student learning motivation. This research is a descriptive study with a quantitative approach, the subjects in this study were 25 students of grade 8 and 9 Junior High School. The results of this study were that many students agreed with the use of websites as alternative learning media during this pandemic and students' high motivation to learn mathematics when using the website with an average percentage of $66.3 \%$. From this research, it can be concluded that the website can be an alternative media for learning mathematics in the midst of this pandemic because the website has various advantages that can also increase student learning motivation.
\end{abstract}

This is an open access article under the CC BY-SA license.

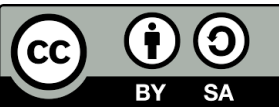

\section{Corresponding Author:}

Weni Dwi Susanti,

Departement of Mathematics Education,

Universitas Islam Riau

Jl. Kaharuddin Nasution No.113, Bukit Raya, Pekanbaru, Riau 28284, Indonesia

Email: wenidwisusanti28@gmail.com

\section{How to Cite:}

Suripah, S., \& Susanti, W. D. (2022). Alternative learning during a pandemic: Use of the website as a mathematics learning media for student motivation. Infinity, 11(1), 17-32.

\section{INTRODUCTION}

The Covid-19 pandemic has hit all countries in the world, including Indonesia. The Covid-19 pandemic has an impact on all sectors of life, such as the economy, health, education and others (Damanhuri, 2020; Susilawati et al., 2020; Zhang \& Ma, 2020). In the education sector, the Covid-19 virus pandemic has stopped educational activities from the lowest levels of education (Pre-Primary School) to higher education. In connection with this, the Minister of Education and Culture of the Republic of Indonesia issued Circular Number: 36962 / MPK.A / HK / 2020, March 17, 2020 regarding Online Learning and Working from Home in the Context of Preventing the Spread of Corona Virus Disease (Covid-19). This 
circular contains 4 important things, (1) study at home through daring or distance learning implement to experience without being burdened to complete the curriculum target for grade promotion or graduation, (2) distance learning can be focused on life skills education example Covid-19, (3) students activities and task could be varied among students in accordance with their interest and condition including learning gap and facilities at home, (4) proof or product activity should be given feedback which is qualitative and useful for teachers without giving a score or quantitative grade.

It is hoped that the sudden change in conditions in the world of education will not hinder the learning process. The government policy regarding learning from home is one of the efforts to prevent the spread of the Covid-19 outbreak widely and to follow up to comply with social distancing and physical distancing rules (Pratomo, 2020; Yanti et al., 2020). Mathematics learning which is part of the school curriculum is also affected by learning from home policy. This needs to be a concern because it is related to the characteristics of mathematics.

Learning mathematics is still considered difficult by many students, this is caused by several factors. First, many students think that the concept of learning mathematics is abstract and difficult to understand (Putra et al., 2018). Because the concept of learning mathematics is considered abstract, there are still many students who have difficulty in solving mathematical problems. Solving these math problems requires problem-solving skills and creativity, because math problems sometimes require complex solutions that require students' creative thinking (Maulidia et al., 2019). In addition to creative thinking, in solving mathematical problems, students' critical thinking skills are also needed to be responsive in solving given problems. But unfortunately, students' critical thinking skills are still low in solving math problems (Rachmawati et al., 2021; Zetriuslita et al., 2017).

Due to some of these factors, making mathematics as a difficult subject to learn so it makes teaching mathematics, especially during this pandemic teachers must be able to prepare learning media to help students understand the concept of learning mathematics. Therefore, there must be a new breakthrough in the online mathematics learning process, namely by utilizing technology so that mathematics learning continues to run optimally (Susanti \& Suripah, 2021). In the use of technology as a media for learning mathematics, teachers are required to be more creative and should take advantage of the facilities offered by information technology (Suripah, 2017). It is intended that the learning media designed or created by the teacher can be easily used by students to understand the mathematics learning material provided.

When a pandemic occurs, many learning media can be used by utilizing information technology. Many teachers have started using the Learning Management System (LMS) platform such as Google Classroom, Edmodo, Schoology and others (Okmawati, 2020; Purnawarman et al., 2016; Roqobih \& Ambarwati, 2020). In addition, teachers also use video conference technology facilities such as Zoom, Google Meet (Fakhruddin, 2018; Sajaril et al., 2020) and create interesting learning videos to upload on YouTube as an alternative learning media for students (Samosir et al., 2018). Another learning alternative that can be used is software such as Geogebra that can visualize mathematical concepts to students (Zetriuslita et al., 2020).

Even though there are many technological facilities that can be used as alternative media during this pandemic, students' motivation to learn mathematics has actually decreased. Several previous studies have shown that student motivation decreases during the online learning process (Gustiani, 2020; Muslimin \& Harintama, 2020; Subakthiasih \& Putri, 2020). The decrease in motivation is caused by several factors, including bad internet network connection, improper media selection, and less conducive learning conditions. Whereas learning motivation is important for every student to have, with learning motivation 
will bring out the intention from within students to continue to carry out learning activities so that the desired goals can be achieved (Cahyani et al., 2020).

Therefore, interactive media is needed and can be the right alternative for use in online learning activities. One of the learning media that can be used in online learning activities is a website. Website is a collection of pages summarized in a domain or subdomain that contains multimedia in the form of audio, text, images and video and can be accessed via a web browser (Destiningrum \& Adrian, 2017; Marisa, 2017). One of the advantages of the website as a learning media is that there is interactive multimedia that can be used in the learning process so that it can encourage student motivation to learn independently (Danaswari \& Gafur, 2018). Based on this, the website becomes an efficient learning media because it can be accessed anywhere and anytime.

Several previous researchs have revealed the advantages of websites as learning media. Study from Ghani and Daud (2018) stated that the use of the website as a learning media can increase the effectiveness of the learning process, and most students feel satisfied and play a more active and critical role in developing their skills. In addition, study from Astuti et al. (2020) stated web-based technology is often the technology of choice for distance education, given the ease of use of tools to browse web resources from any device, and the relative affordability of accessing them anywhere, websites can also be easily designed using the multiple online platforms available. In addition to having advantages, the use of websites as learning media also has disadvantages. Based on Andriasari (2017) opinion, the disadvantages of using the website include: (1) it requires a stable internet connection, this is intended so that the website can be accessed properly and smoothly, (2) a good security system is needed, so that the server does not drop when accessed by users simultaneously.

The findings from this study will help advance our understanding of the integration of the use of websites as alternative learning media in the midst of the Covid-19 pandemic on student learning motivation. Therefore, this study adds valuable insight into alternative learning media that can be used during online learning and increases student motivation in learning mathematics. To achieve this goal, this study aspires to answer questions (1) How is the use of the website as an alternative learning media during the pandemic? and (2) How do students' motivation when using the website as an alternative learning media?

\section{METHOD}

\subsection{Research Design}

This research is a descriptive study with a quantitative approach. In this study, it will be known how much intensity the students use of the website as a learning media (see Figure 1). The website accessed by students is a website developed by the researchers themselves using Google Sites. The subject matter contained on the website was also developed by researchers in the form of 8th and 9th grade mathematics subject matter. In addition, it will also be known how much student motivation when using the website. In line with Seixas et al. (2018), this approach will focus on the latest problems and phenomena that are happening in the form of research results in the form of numbers that have meaning about the use of websites on student motivation. 


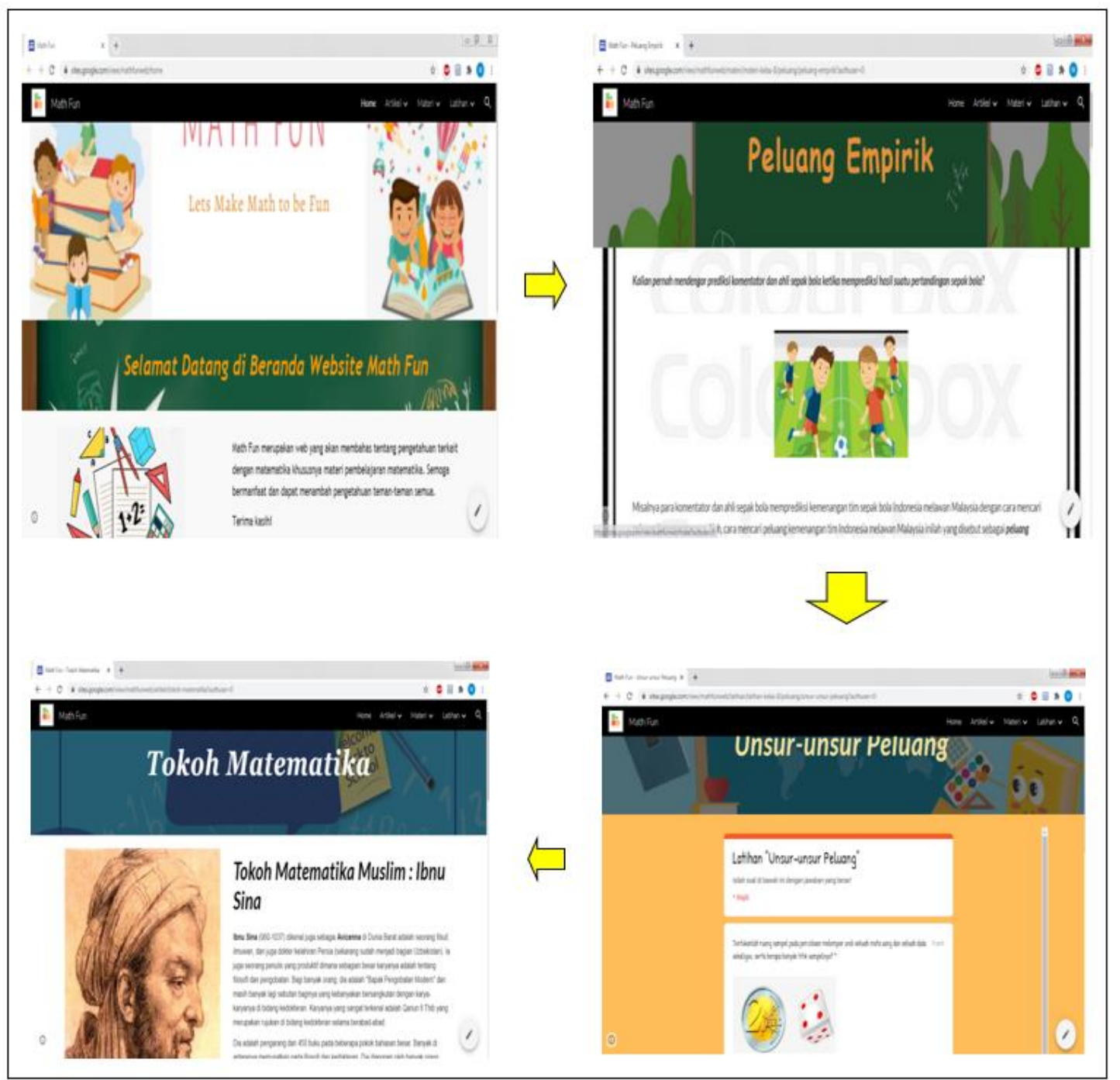

Figure 1. The example of interface an educational website

\subsection{Participant}

In this study, the sampling technique was random sampling. This is because researchers cannot limit someone from other institutions. Researchers only limit, the subjects in this study were students in grade 8 and 9 Junior High School. Researchers do not limit gender, school name, age of respondents, or others. This study involved 25 students from grade 8 and 9 Junior High School. Among them, 25 students came from 2 different schools, namely Nurul Falah Kulim Junior High School, and from 3 Pekanbaru Junior High School. Researchers only conducted research on some 8th and 9th grade students due to limitations in conducting exploration in the midst of the current Covid-19 pandemic, requiring researchers to conduct research online.

\subsection{Research Instruments}

The instrument in this study was made by researchers, research instrument in the form of a questionnaire made from Google Form and then distributed to research subjects. Researchers collected data through questionnaire from Google Form that consisting of 22 
questions. Before filling out the questionnaire, the researcher will provide a website link on the research subject. After that, the researcher will ensure that the website is seen by the research subject through his absence from the website. During the online learning process, the researcher will ensure the presence of each research subject through absence. The questionnaire will be filled in by grade 8 and 9 junior high school students. Of the 20 question consisted: 2 question contains about participant's profile such as name and class; 5 questions contained about the intensity of students using the website; 5 questions contained about the purpose of accessing the website; 5 questions contained about desire in learning: and 5 questions contained about interest in learning.

Before the questionnaires were distributed to the research subjects, the researchers first validated the content of the 8th and 9th grade junior high school mathematics curriculum standards. The next stage, learning tools, media and questionnaires were consulted with experts in this case were 2 mathematics education lecturers. Based on the input given, the researcher improved the media according to the suggestions and inputs until the media that had been made by the researcher was declared valid. While the questionnaire that have been consturcted based on indicators of learning motivation according to theoretical studies to be used as a questionnaire item for student learning motivation. The items that have been constructed will then be validated by experts and further revised according to expert advice until the questionnaire is declared valid.

\subsection{Data Collection and Analysis}

Data was collected using Google Form as online survey. Google Form are used for reasons of the efficiency and flexebility of compability with students' learning during a pandemic, and because its easy to use. The questionnaire are disseminated through WhatsApp groups and emails. After the respondents fills in the questionnaire, the researchers will get a recapitulation results. The data obtained about the intensity of students using website, the purposes of accesing the website, students' desire learning, and students' interest in learning. The data obtained is then interpreted and described by researchers.

\section{RESULTS AND DISCUSSION}

\subsection{Results}

The results of a survey of respondents who were taken as participants in this study found that in the usage intensity section, students in general were able to access several mathematics learning websites during the Covid-19 pandemic.

Table 1. The survey results of respondents in usage intensity

\begin{tabular}{|c|c|c|c|c|c|}
\hline \multirow[b]{2}{*}{ Indicators } & \multirow{2}{*}{$\begin{array}{c}\text { Sub } \\
\text { Indicators }\end{array}$} & \multirow[b]{2}{*}{ Items } & \multicolumn{2}{|c|}{ Frequency } & \multirow{2}{*}{$\begin{array}{c}\text { Percentage } \\
(\%)\end{array}$} \\
\hline & & & Score & $\begin{array}{l}\text { Maximum } \\
\text { Amount }\end{array}$ & \\
\hline \multirow{3}{*}{$\begin{array}{l}\text { Usage } \\
\text { Intensity }\end{array}$} & \multirow{3}{*}{$\begin{array}{l}\text { Understand } \\
\text { student use } \\
\text { of websites }\end{array}$} & $\begin{array}{l}\text { I use the website in math } \\
\text { learning activities }\end{array}$ & 79 & 100 & $79 \%$ \\
\hline & & $\begin{array}{l}\text { I use the website to find math } \\
\text { subject matter }\end{array}$ & 76 & 100 & $76 \%$ \\
\hline & & $\begin{array}{l}\text { When doing assignments } \\
\text { from teachers, I was not } \\
\text { interested in finding } \\
\text { information on the website }\end{array}$ & 48 & 100 & $48 \%$ \\
\hline
\end{tabular}




\begin{tabular}{|c|c|c|c|c|c|}
\hline \multirow{4}{*}{ Indicators } & \multirow{2}{*}{$\begin{array}{c}\text { Sub } \\
\text { Indicators }\end{array}$} & \multirow[b]{2}{*}{ Items } & \multicolumn{2}{|c|}{ Frequency } & \multirow{2}{*}{$\begin{array}{l}\text { Percentage } \\
\quad(\%)\end{array}$} \\
\hline & & & Score & $\begin{array}{c}\text { Maximum } \\
\text { Amount }\end{array}$ & \\
\hline & \multirow{2}{*}{$\begin{array}{l}\text { Understand } \\
\text { the time to } \\
\text { use the } \\
\text { website }\end{array}$} & $\begin{array}{l}\text { I access math learning } \\
\text { websites when I have free } \\
\text { time }\end{array}$ & 67 & 100 & $67 \%$ \\
\hline & & $\begin{array}{l}\text { I can't take the time to access } \\
\text { maths learning websites } \\
\text { every day }\end{array}$ & 59 & 100 & $59 \%$ \\
\hline \multicolumn{3}{|c|}{ Total } & 329 & 500 & $329 \%$ \\
\hline \multicolumn{5}{|c|}{ Average } & $65.8 \%$ \\
\hline
\end{tabular}

Table 1 shows that the intensity of using the website by respondents is quite high. From this table, it can be seen that respondents often use the website when learning mathematics and looking for mathematics teaching materials. However, when using the website, some respondents still did not take full advantage of the website. This can be seen from the results in the table, where only $48 \%$ of respondents access learning websites during their spare time and $59 \%$ of respondents have time to access learning websites every day.

The results of the survey of respondents who were used as participants in this study found that in the section on the purpose of accessing the website, most of the students understood the use of the website as a source of information and independent learning resources, so they always studied independently and found out things related to mathematics learning. Especially in conditions of the Covid-19 pandemic like this, students are required to learn independently by utilizing existing technology (see Table 2)

Table 2. The survey results of respondents in the purpose of accessing the website

\begin{tabular}{|c|c|c|c|c|c|}
\hline \multirow[b]{2}{*}{ Indicators } & \multirow{2}{*}{$\begin{array}{c}\text { Sub } \\
\text { Indicators }\end{array}$} & \multirow[b]{2}{*}{ Items } & \multicolumn{2}{|c|}{ Frequency } & \multirow{2}{*}{$\begin{array}{l}\text { Percentage } \\
(\%)\end{array}$} \\
\hline & & & Score & $\begin{array}{c}\text { Maximum } \\
\text { Amount }\end{array}$ & \\
\hline \multirow{5}{*}{$\begin{array}{l}\text { Purpose of } \\
\text { Accessing } \\
\text { the } \\
\text { Website }\end{array}$} & \multirow{2}{*}{$\begin{array}{l}\text { Using the } \\
\text { website as a } \\
\text { means of } \\
\text { information }\end{array}$} & $\begin{array}{l}\text { I use the website as a means } \\
\text { of getting the latest learning } \\
\text { information }\end{array}$ & 80 & 100 & $80 \%$ \\
\hline & & $\begin{array}{l}\text { I use the website to find } \\
\text { information on the latest } \\
\text { movies and games }\end{array}$ & 61 & 100 & $61 \%$ \\
\hline & \multirow{3}{*}{$\begin{array}{l}\text { Using the } \\
\text { website as a } \\
\text { learning } \\
\text { resource }\end{array}$} & $\begin{array}{l}\text { I use the website as a } \\
\text { substitute learning resource } \\
\text { when the teacher cannot carry } \\
\text { out face-to-face learning }\end{array}$ & 74 & 100 & $74 \%$ \\
\hline & & $\begin{array}{l}\text { I use the website as a learning } \\
\text { resource and media to access } \\
\text { math learning materials }\end{array}$ & 77 & 100 & $77 \%$ \\
\hline & & $\begin{array}{l}\text { I use this website as a } \\
\text { complementary media to } \\
\text { access learning materials and } \\
\text { gain insight and knowledge } \\
\text { about mathematics }\end{array}$ & 76 & 100 & $76 \%$ \\
\hline \multicolumn{3}{|c|}{ Total } & 368 & 500 & $368 \%$ \\
\hline & & Average & & & $73.6 \%$ \\
\hline
\end{tabular}


Table 2 shows that many students use websites as learning resources during the Covid-19 pandemic. This can be seen from the results in the table, where around $74 \%$ of respondents access the website as a substitute learning source when they cannot do face-toface learning activities, $80 \%$ use the website to access mathematics learning material, and $76 \%$ of respondents use the website as a complementary media to add to their insights However, for the use of the website as information, there are still some students who aim to access information on the website for entertainment such as playing games and looking for movies.

The results of a survey of respondents who were taken as participants in this study found that in the part of the desire in learning, most of the students showed a great desire to learn when using the website as an alternative to their learning media. The presentation of attractive material and information that is easy to understand is able to attract the attention of students to use the website in the learning process (see Table 3).

Table 3. The survey results of respondents in desire in learning

\begin{tabular}{|c|c|c|c|c|c|}
\hline \multirow[b]{2}{*}{ Indicators } & \multirow{2}{*}{$\begin{array}{c}\text { Sub } \\
\text { Indicators }\end{array}$} & \multirow[b]{2}{*}{ Items } & \multicolumn{2}{|c|}{ Frequency } & \multirow{2}{*}{$\begin{array}{c}\text { Percentage } \\
(\%)\end{array}$} \\
\hline & & & Score & $\begin{array}{c}\text { Maximum } \\
\text { Amount }\end{array}$ & \\
\hline \multirow{5}{*}{$\begin{array}{l}\text { Desire in } \\
\text { Learning }\end{array}$} & \multirow{5}{*}{$\begin{array}{l}\text { Students' } \\
\text { attention when } \\
\text { participating in } \\
\text { mathematics } \\
\text { learning }\end{array}$} & $\begin{array}{l}\text { I'm excited to use the } \\
\text { website to find math } \\
\text { learning materials }\end{array}$ & 78 & 100 & $78 \%$ \\
\hline & & $\begin{array}{l}\text { Using the website } \\
\text { helps me understand } \\
\text { math learning material }\end{array}$ & 75 & 100 & $75 \%$ \\
\hline & & $\begin{array}{l}\text { By displaying } \\
\text { interesting material on } \\
\text { the website, it makes } \\
\text { me even more excited } \\
\text { about the mathematics } \\
\text { learning process }\end{array}$ & 81 & 100 & $81 \%$ \\
\hline & & $\begin{array}{l}\text { Learning math using } \\
\text { the website makes me } \\
\text { feel bored }\end{array}$ & 38 & 100 & $38 \%$ \\
\hline & & $\begin{array}{l}\text { I feel hopeless while } \\
\text { working on math } \\
\text { problems }\end{array}$ & 37 & 100 & $37 \%$ \\
\hline \multicolumn{3}{|c|}{ Total } & 309 & 500 & $309 \%$ \\
\hline & & Average & & & $61.8 \%$ \\
\hline
\end{tabular}

Table 3 shows that many students expressed their concerns when using the website. Website material is presented with interactive multimedia which is able to attract students' attention in learning mathematics. This can be seen from the results in the table that $81 \%$ of respondents better understand mathematics learning materials using websites and also only a small proportion of respondents feel bored when using the website as a learning media. This means that students' desire to learn is high enough when using the website as an alternative media for learning mathematics

The results of a survey of respondents who were taken as participants in this study found that in the part of interest in learning, most students showed their interest in using the website. The interactive presentation of material on the website can increase students' curiosity and enjoyment in the learning process (see Table 4). 
Table 4. The survey results of respondents in interest in learning

\begin{tabular}{|c|c|c|c|c|c|}
\hline \multirow[t]{2}{*}{ Indicator } & \multirow{2}{*}{$\begin{array}{c}\text { Sub } \\
\text { Indicator }\end{array}$} & \multirow[t]{2}{*}{ Items } & \multicolumn{2}{|c|}{ Frequency } & \multirow{2}{*}{$\begin{array}{c}\text { Percentage } \\
(\%)\end{array}$} \\
\hline & & & Score & $\begin{array}{l}\text { Maximum } \\
\text { Amount }\end{array}$ & \\
\hline \multirow{7}{*}{$\begin{array}{l}\text { Interest } \\
\text { in } \\
\text { Learning }\end{array}$} & \multirow{5}{*}{$\begin{array}{c}\text { Students' } \\
\text { curiosity } \\
\text { when taking } \\
\text { mathematics } \\
\text { lessons }\end{array}$} & $\begin{array}{l}\text { I feel happy trying to do math } \\
\text { problems using the website }\end{array}$ & 81 & 100 & $81 \%$ \\
\hline & & $\begin{array}{l}\text { If I have trouble understanding } \\
\text { the material, I look for more } \\
\text { information on the website }\end{array}$ & 79 & 100 & $79 \%$ \\
\hline & & $\begin{array}{l}\text { I postpone doing assignments } \\
\text { given by the teacher even } \\
\text { though I use the website }\end{array}$ & 43 & 100 & $43 \%$ \\
\hline & & $\begin{array}{l}\text { I am interested in finding other } \\
\text { study materials on the website }\end{array}$ & 78 & 100 & $78 \%$ \\
\hline & & $\begin{array}{l}\text { I am not interested in learning } \\
\text { mathematics because I am } \\
\text { always given assignments }\end{array}$ & 39 & 100 & $39 \%$ \\
\hline & \multicolumn{2}{|r|}{ Total } & 320 & 500 & $320 \%$ \\
\hline & & Average & & & $64 \%$ \\
\hline
\end{tabular}

Table 4 shows that many students are increasingly curious when using the website as an alternative learning media. Many of them want to use the website for subjects other than math. This can be seen from the results in the table, $78 \%$ of respondents are interested in using websites for other subjects and $81 \%$ of respondents like to use websites when learning mathematics. Only a small proportion of them are not interested in using websites and learning math.

Based on indicators 1 to 4 , the total score can be visualized in the Table 5.

Table 5. Percentage of website usage on student learning motivation

\begin{tabular}{llc}
\hline No. & \multicolumn{1}{c}{ Indicators } & Percentage (\%) \\
\hline 1. & Usage Intensity & $65.8 \%$ \\
\hline 2. & The Purpose of Accessing the Website & $73.6 \%$ \\
\hline 3. & Desire in Learning & $61.8 \%$ \\
\hline 4. & Interest in Learning & $64 \%$ \\
\hline & Average & $66.3 \%$ \\
\hline
\end{tabular}

Table 5 show the percentage of total indicators of using the website as a media for learning mathematics on student learning motivation. Based on the interpretation criteria of the modified students' learning motivation scores from Riduwan (2010) (see Table 6), the average percentage of student learning motivation is $66.3 \%$. So that based on these results student learning motivation when using the website as a learning media can be categorized as high. 
Table 6. Interpretation criteria for student learning motivation scores

\begin{tabular}{ccc}
\hline No. & Motivation Range & $\begin{array}{c}\text { Interpretation Criteria } \\
\text { for Mathematics Learning Motivation }\end{array}$ \\
\hline 1. & $0 \% \leq$ Motivation $\leq 20 \%$ & Very low motivation \\
\hline 2. & $21 \% \leq$ Motivation $\leq 40 \%$ & Low motivation \\
\hline 3. & $41 \% \leq$ Motivation $\leq 60 \%$ & Enough motivation \\
\hline 4. & $61 \% \leq$ Motivation $\leq 80 \%$ & High motivation \\
\hline 5. & $81 \% \leq$ Motivation $\leq 100 \%$ & Very high motivation \\
\hline
\end{tabular}

Based on these results, the use of websites as a media for learning mathematics can increase student motivation. The interactive presentation of material, easy-to-understand information, and easy access makes the website an alternative learning media which is quite effective to use during online learning. The use of websites in mathematics learning can increase students' enthusiasm and curiosity. So that the website can be used as an alternative learning media in the midst of this pandemic.

\subsection{Discussion}

In addition to discussing the use of websites as alternative media for learning mathematics for student motivation, this study also discusses choosing the right alternative learning media in the midst of this pandemic. In the findings of this study, there are two important points. First, this study shows that the website is a learning media to support elearning; several previous studies have also shown that the website is a learning media that is often used in e-learning (Astuti et al., 2020; Dogan \& Dikbıyık, 2016; Hamdunah et al., 2016; Lestari, 2019; Usta, 2011), however teachers still have difficulty applying math concepts on the website. This is because teaching math concepts is very difficult for teachers (Indriani et al., 2018; Maulydia et al., 2017), and also added to the factor of teachers who still have difficulty teaching online (Karal et al., 2015; Kebritchi et al., 2017; Wang \& Ip, 2010). Many teachers have understood the selection of alternative media during the pandemic, including using Learning Management Systems (LMS) (eg Google Classroom and Edmodo) as well as facilities such as video conference (eg Zoom and Google Meet). Based on this, it means that many teachers have mastered the use of technology even before this pandemic. For the selection of appropriate alternatives during this pandemic, teachers must be able to adapt again and adapt the media to the needs of students. Website can be an alternative because it contains multimedia and the information conveyed is easy to understand.

Based on the results of the study, the intensity of using the website as a media for learning mathematics is quite high, of which about $79 \%$ of students use the website for mathematics learning activities. The intensity of the use of the website is quite high, due to the ease of accessing the website freely and also the design on the website is simple but able to attract the attention of students in learning activities. This is supported by opinion (Gautam et al., 2020; Lestari, 2019; Muhardi et al., 2020; Permatasari et al., 2019) who said that the website is one of the e-learning media that can be accessed easily compared to other platforms such as Moodle, Schoology, and Edmodo. In addition, learning materials on the website can also be presented in various forms such as word, PDF, powerpoint, HTML and the advantages of website design with various interactive menus. This is what makes many students interested in using the website as a media for learning mathematics, as evidenced 
by the results of research on the indicators of the purpose of using the website as many as $77 \%$ of students use the website to access mathematics learning materials and as many as $76 \%$ access the website with the aim of increasing their mathematical knowledge.

Second, the results showed that many students used the website as an alternative learning media. Some of the existing indicators even show that student learning motivation increases with the use of websites as a media for learning mathematics. Based on the results of the study on indicators of desire in learning, as many as $78 \%$ of students were excited about looking for mathematics learning on the website, in this case the use of interactive multimedia had an important effect in increasing students' enthusiasm for learning. The use of multimedia in the form of audio, text, video, and animation increases student motivation during the learning process (Almara'beh et al., 2015; Leow \& Neo, 2014; Maria et al., 2019; Nasrum \& Herlina, 2019; Setiawan et al., 2015). Using this website can better support the online learning system in the midst of this pandemic besides using the Learning Management System (LMS) platform, video conferencing, and others (Djamdjuri \& Kamilah, 2020; Handayani \& Utami, 2020; Lubis \& Sari, 2020; Nartiningrum \& Nugroho, 2020; Putri \& Irwansyah, 2020; Wiratomo \& Mulyatna, 2020). This is evident from the results of the study, as many as $81 \%$ of students feel happy when using the website to solve mathematical problems.

Website is one of the media that can be accessed anywhere and anytime, this is one of the supporting factors to increase student motivation in using the website. The use of the website is also simple, by clicking on the website link students can directly link to the website homepage. Based on opinion Susanti and Suripah (2021), website is one of the effective mathematics learning media used during online learning activities. With these advantages, making the website a more effective learning media than other platforms that can be accessed freely. This can be seen from the results of research that average percentage of student learning motivation is $66.3 \%$. So that based on these results student learning motivation when using the website as a learning media can be categorized as high.

This study examines the use of websites as an alternative media for learning mathematics towards student motivation, it is not easy to choose the right media to use during this pandemic, there are many limitations and obstacles encountered in each lesson. However, teachers and students must be able to adapt to these changes, namely by trying to make optimal use of existing information technology, one of which is accessing the website to develop mathematical insights.

\section{CONCLUSION}

This study concludes that the website can be an alternative learning media during this pandemic. Based on the intensity of use and intended use, it is known that students are interested in using websites in the mathematics learning process. In addition, the use of websites as a media for learning mathematics can also increase motivation. with an attractive presentation of material, easy access, and easy-to-understand information to make students more motivated in the mathematics learning process. Students' attention and curiosity when accessing mathematics learning materials on the website increase their learning motivation. The use of the website is also recommended for use in other subjects. 


\section{ACKNOWLEDGEMENTS}

The authors would like to thank the lectures for their support and guidance so far, and also some students who participated in filling out the questionnaire. Without them this research will not be done.

\section{REFERENCES}

Almara'beh, H., Amer, E. F., \& Sulieman, A. (2015). The effectiveness of multimedia learning tools in education. International Journal of Advanced Research in Computer Science and Software Engineering, 5(12), 761-764.

Andriasari, S. (2017). Pengembangan aplikasi e-commerce menggunakan metode wisdm (web information system developmnet methodology) (Studi kasus: PT. sinar jati meubel Bandar Lampung) [E-commerce application development using WISDM method (web information system developmnet methodology) (Case study: PT. sinar jati meubel Bandar Lampung)]. Jurnal Cendikia, 14(2), 8-15.

Astuti, L., Wihardi, Y., \& Rochintaniawati, D. (2020). The development of web-based learning using interactive media for science learning on levers in human body topic. Journal of Science Learning, 3(2), 89-98. https://doi.org/10.17509/jsl.v3i2.19366

Cahyani, A., Listiana, I. D., \& Larasati, S. P. D. (2020). Motivasi belajar siswa SMA pada pembelajaran daring di masa pandemi COVID-19 [High school students' learning motivation in online learning during the COVID-19 pandemic]. IQ (Ilmu Al-qur'an): Jurnal Pendidikan Islam, 3(01), 123-140. https://doi.org/10.37542/iq.v3i01.57

Damanhuri, D. (2020). Student learning motivation in the pandemic time COVID-19. In Prosiding Seminar Nasional Pendidikan FKIP UNTIRTA.

Danaswari, C., \& Gafur, A. (2018). Multimedia pembelajaran berbasis web pada mata pelajaran akuntansi SMA untuk peningkatan motivasi dan hasil belajar [Multimedia web-based learning in high school accounting subjects to increase motivation and learning outcomes]. Jurnal Inovasi Teknologi Pendidikan, 5(2), 204-218. https://doi.org/10.21831/jitp.v5i2.15543

Destiningrum, M., \& Adrian, Q. J. (2017). Sistem informasi penjadwalan dokter Berbassis web dengan menggunakan Framework Codeigniter (Studi kasus: Rumah Sakit Yukum Medical Centre) [Web-based doctor scheduling information system using Codeigniter Framework (Case study: Yukum Medical Center Hospital)]. Jurnal Teknoinfo, 11(2), 30-37.

Djamdjuri, D. S., \& Kamilah, A. (2020). Whatsapp media in online learning during COVID19 pandemic. English Journal, 14(2), 69-74. https://doi.org/10.32832/english.v14i2.3792

Dogan, B., \& Dikbıyık, E. (2016). OPCOMITS: Developing an adaptive and intelligent web based educational system based on concept map model. Computer Applications in Engineering Education, 24(5), 676-691. https://doi.org/10.1002/cae.21740

Fakhruddin, A. (2018). Using Google Meet in teaching speaking. Journal of English Langage Learning (JELL), 2(2), 43-46.

Gautam, V., Khandelwal, S., \& Dwivedi, R. (2020). The Impact of Self-Efficacy and Need for Achievement on Management Students' Perceptions Regarding Web Based 
Learning Resources. International Journal of Education and Development using Information and Communication Technology, 16(2), 68-83.

Ghani, M. T. A., \& Daud, W. A. A. W. (2018). Adaptation of ADDIE instructional model in developing educational website for language learning. Global Journal AlThaqafah, 8(2), 7-16.

Gustiani, S. (2020). Students' motivation in online learning during COVID-19 pandemic era: A case study. HOLISTICS, 12(2), 23-40.

Hamdunah, H., Alfi, Y., Zulkardi, Z., \& Muhafzan, M. (2016). Development a constructivist module and web on circle and sphere material with Wingeom software. Humaniora, 7(2), 57-128.

Handayani, T., \& Utami, N. (2020). The effectiveness of hybrid learning in character building of integrated Islamic elementary school students during the COVID-19 pandemic. Journal of Educational Science and Technology (EST), 6(3), 276-283.

Indriani, R., Darta, D., \& Dahlan, T. (2018). The difficulties teaching mathematics material according to students perception. In Proceeding International Conference on Education, ICE (International Conference on Education) FKIP Unpas.

Karal, H., Kokoc, M., Colak, C., \& Yalcin, Y. (2015). A case study on online mathematics teaching with pen-based technology: Experiences of two instructors. Contemporary Educational Technology, 6(4), 319-337. https://doi.org/10.30935/cedtech/6157

Kebritchi, M., Lipschuetz, A., \& Santiague, L. (2017). Issues and challenges for teaching successful online courses in higher education: A literature review. Journal of Educational Technology Systems, 46(1), 4-29. https://doi.org/10.1177/0047239516661713

Leow, F.-T., \& Neo, M. (2014). Interactive multimedia learning: Innovating classroom education in a Malaysian university. Turkish Online Journal of Educational Technology-TOJET, 13(2), 99-110.

Lestari, A. S. (2019). The development of web learning based on project in the learning media course at IAIN Kendari. Jurnal Pendidikan Islam, 5(1), 39-52. https://doi.org/10.15575/jpi.v5i1.2909

Lubis, M. J., \& Sari, L. P. (2020). The online learning activities during the COVID-19 pandemic. Budapest International Research and Critics Institute (BIRCI-Journal): Humanities and Social Sciences, 3(4), 3619-3624.

Maria, U., Rusilowati, A., \& Hardyanto, W. (2019). Interactive multimedia development in the learning process of Indonesian culture introduction theme for 5-6 year old children. Journal of Primary Education, 8(3), 344-353.

Marisa, F. (2017). Web Programming (Client Side and Server Side). Deepublish.

Maulidia, F., Johar, R., \& Andariah, A. (2019). A case study of students' creativity in solving mathematical problems through problem based learning. Infinity Journal, 8(1), 1-10. https://doi.org/10.22460/infinity.v8i1.p1-10

Maulydia, S. S., Surya, E., \& Syahputra, E. (2017). The development of mathematic teaching material through realistic mathematics education to increase mathematical problem solving of junior high school students. International Journal Of Advance Research And Innovative Ideas In Education, 3(2), 2965-2971. 
Muhardi, M., Gunawan, S. I., Irawan, Y., \& Devis, Y. (2020). Design of web based LMS (learning management system) in SMAN 1 Kampar Kiri Hilir. Journal of Applied Engineering and Technological Science (JAETS), 1(2), 70-76.

Muslimin, A. I., \& Harintama, F. (2020). Online learning during pandemic: Students' motivation, challenges, and alternatives. Loquen: English Studies Journal, 13(2), 6068. https://doi.org/10.32678/loquen.v13i2.3558

Nartiningrum, N., \& Nugroho, A. (2020). Online learning amidst global pandemic: EFL students' challenges, suggestions, and needed materials. ENGLISH FRANCA: Academic Journal of English Language and Education, 4(2), 115-140. https://doi.org/10.29240/ef.v4i2.1494

Nasrum, A., \& Herlina, H. (2019). Developing of calculus teaching materials based on $\begin{array}{llll}\text { audiovisual. Infinity } & \text { Journal, }\end{array}$ https://doi.org/10.22460/infinity.v8i2.p209-218

Okmawati, M. (2020). The use of Google Classroom during pandemic. Journal of English Language Teaching, 9(2), 438-443. https://doi.org/10.24036/jelt.v9i2.109293

Permatasari, G. A., Ellianawati, E., \& Hardyanto, W. (2019). Online web-based learning and assessment tool in vocational high school for physics. Jurnal Penelitian \& Pengembangan Pendidikan Fisika, 5(1), 1-8. https://doi.org/10.21009/1.05101

Pratomo, H. (2020). From social distancing to physical distancing: A challenge for evaluating public health intervention against COVID-19. Kesmas: Jurnal Kesehatan masyarakat nasional (National Public Health Journal), 1(1), 60-63. https://doi.org/10.21109/kesmas.v15i2.4010

Purnawarman, P., Susilawati, S., \& Sundayana, W. (2016). The use of Edmodo in teaching writing in a blended learning setting. Indonesian Journal of Applied Linguistics, 5(2), 242-252. https://doi.org/10.17509/ijal.v5i2.1348

Putra, J., Suryadi, D., \& Juandi, D. (2018). Mathematical abstraction ability of prospective math teacher students. Journal of Physics: Conference Series, 1132(1), 012049. https://doi.org/10.1088/1742-6596/1132/1/012049

Putri, A. V., \& Irwansyah, I. (2020). Communication patterns and media technology role in organization and society during pandemic. The Journal of Society and Media, 4(2), 228-261. https://doi.org/10.26740/jsm.v4n2.p228-261

Rachmawati, L. N., Cholily, Y. M., \& Zukhrufurrohmah, Z. (2021). Mathematics communication mistakes in solving HOTs problems. Infinity Journal, 10(1), 69-80. https://doi.org/10.22460/infinity.v10i1.p69-80

Riduwan, R. (2010). Belajar mudah peneliti untuk guru-karyawan dan peneliti pemula. Alfabeta.

Roqobih, F. D., \& Ambarwati, R. (2020). Implementation of blended learning using schoology on the topic of invertebrate to improve student learning outcomes. Jurnal Inovasi Pembelajaran Biologi, 1(1), 24-34.

Sajaril, A. E., Rahmatia, R., \& Syahira, S. (2020). The Student perspectives on the effectiveness of zoom meeting media in increasing knowledge of thesis writing at STKIP Muhammadiyah Manokwari. International Journal of Education, Information Technology, and Others, 3(2), 333-337. https://doi.org/10.5281/zenodo.3987204 
Samosir, F. T., Pitasari, D. N., Purwaka, P., \& Tjahjono, P. E. (2018). The effectiveness of youtube as a student learning media (study at the faculty of social and political sciences, University of Bengkulu). Record and Library Journal, 4(2), 81-91. https://doi.org/10.20473/rlj.V4-I2.2018.81-91

Seixas, B. V., Smith, N., \& Mitton, C. (2018). The qualitative descriptive approach in international comparative studies: using online qualitative surveys. International Journal of Health Policy and Management, 7(9), 778-781. https://doi.org/10.15171/ijhpm.2017.142

Setiawan, H., Isnaeni, W., Budijantoro, F. P. M. H., \& Marianti, A. (2015). Implementation of digital learning using interactive multimedia in excretory system with virtual laboratory. REID (Research and Evaluation in Education), 1(2), 212-224. https://doi.org/10.21831/reid.v1i2.6501

Subakthiasih, P., \& Putri, I. G. A. V. W. (2020). An analysis of students' motivation in studying English during COVID-19 pandemic. Linguistic, English Education and Art (LEEA) Journal, 4(1), 126-141. https://doi.org/10.31539/leea.v4i1.1728

Suripah, S. (2017). Mengembangkan keterampilan mengajar berbasis ICT bagi calon guru abad XXI. In KMP Education Research Conference - Keluarga Mahasiswa Pascasarjana (KMP) Universitas Negeri Yogyakarta 2017. Retrieved from: http://repository.uir.ac.id/id/eprint/2086

Susanti, W. D., \& Suripah, S. (2021). The effectiveness of website as a mathematics learning media during the online learning period. Edumatica: Jurnal Pendidikan Matematika, 11(01), 73-83. https://doi.org/10.22437/edumatica.v11i01.12225

Susilawati, S., Falefi, R., \& Purwoko, A. (2020). Impact of COVID-19's pandemic on the economy of Indonesia. Budapest International Research and Critics Institute (BIRCI-Journal): Humanities and Social Sciences, 3(2), 1147-1156. https://doi.org/10.33258/birci.v3i2.954

Usta, E. (2011). The effect of web-based learning environments on attitudes of students regarding computer and internet. Procedia - Social and Behavioral Sciences, 28, 262-269. https://doi.org/10.1016/j.sbspro.2011.11.051

Wang, M., \& Ip, K. I. (2010). Tasks and challenges faced by teachers in handling an online project. Asian EFL Journal, 12(4), 143-158.

Wiratomo, Y., \& Mulyatna, F. (2020). Use of learning management systems in learning efforts during a pandemic. Journal of Mathematical Pedagogy (JoMP), 1(2), 62-71.

Yanti, B., Mulyadi, E., Wahiduddin, W., Novika, R. G. H., Arina, Y. M. D. a., Martani, N. S., \& Nawan, N. (2020). Community knowledge, attitudes, and behavior towards social distancing policy as prevention transmission of COVID-19 in indonesia. Jurnal Administrasi Kesehatan Indonesia, 8, 4-14.

Zetriuslita, Z., Nofriyandi, N., \& Istikomah, E. (2020). The effect of geogebra-assisted direct instruction on students'self-efficacy and self-regulation. Infinity Journal, 9(1), 4148. https://doi.org/10.22460/infinity.v9i1.p41-48

Zetriuslita, Z., Wahyudin, W., \& Jarnawi, J. (2017). Mathematical critical thinking and curiosity attitude in problem based learning and cognitive conflict strategy: A study in number theory course. International Education Studies, 10(7), 65-78. https://doi.org/10.5539/ies.v10n7p65 
Zhang, Y., \& Ma, Z. F. (2020). Impact of the COVID-19 pandemic on mental health and quality of life among local residents in Liaoning Province, China: A cross-sectional study. International Journal of Environmental Research and Public Health, 17(7), 2381. https://doi.org/10.3390/ijerph17072381 
